\title{
PENGARUH DOUBLE CHAMFER TERHADAP DISTRIBUSI SUHU DAN DAERAH ZpI PADA SAMBUNGAN LAS GESEK AL6061 DENGAN SIMULASI KOMPUTER
}

Welding is one of the metal joining processes in manufacturing. $C D F W$ (continuous drive friction welding) is a welding process to join two workpieces by applying pressure at one end of the object and rotating another one where the friction action applies at interface. The purpose of this study is to study temperature distribution on the surface of the welding area and the heat-affected zone represented by a fully plasticized zone $(\mathrm{Zpl})$ and to get an insight of a friction welding process. The variables of CDFW used were double chamfer angle, upset pressure, and burn off length. The initial area of friction was equal that is at a diameter of $14 \mathrm{~mm}$. The method of modeling the CDFW friction welding is via computer simulations using ANSYS 18.1 software. This research uses aluminum material type Al6061. The Taguchi method was applied in designing the simulations. In this modeling, the model with the double chamfer of $15^{\circ}$, the upset pressure of $120 \mathrm{MPa}$, and the burn-off length of $9 \mathrm{~mm}$ has a small ZPl area of $10.256 \mathrm{~mm}^{2}$. Whilst the specimen model, with a double chamfer angle of $45^{\circ}$, the upset pressure of $240 \mathrm{MPa}$, and the burn-off length of $7 \mathrm{~mm}$ has a large $\mathrm{Zpl}$ area of $56.55 \mathrm{~mm}^{2}$. The area of a narrow fully plasticized area caused by small chamfer angle and an upset pressure of $240 \mathrm{MPa}$. The area of fully plasticized zone shows how much material can be integrated during the friction welding process and how much strength of the weld metal. The model with the chamfer angle of $15^{\circ}$, the upset pressure of $240 \mathrm{MPa}$, and the burn-off length of $9 \mathrm{~mm}$ has the widest temperature distribution and the highest maximum temperature. Meanwhile, the model with the chamfer angle of $30^{\circ}$, the upset pressure of $120 \mathrm{MPa}$, and the burn-off length of $9 \mathrm{~mm}$ has the narrowest temperature distribution and the lowest maximum temperature. The smaller chamfer angle increased upset pressure and burn-off length result in the wider temperature distribution, higher maximum temperature, and smaller $\mathrm{Zpl}$.

Keywords: Continuous Drive Friction Welding, Upset Pressure, Burn-Off Length, Fully Plasticized Zone, Temperature Distribution

\section{PENDAHULUAN}

Kebutuhan masyarakat dengan perkembangan teknologi yang semakin maju menyebabkan permintaan produk dalam bidang industri meningkat. Dalam industri logam ada beberapa metode yang digunakan untuk membentuk logam seperti pengelasan, penempaan, pengecoran, dan permesinan. Logam sendiri merupakan bahan baku dari pembuatan produk. Salah satu logam yang sering digunakan adalah aluminium.

Aluminium adalah logam ringan yang mempunyai ketahanan korosi yang baik. Aluminium tidak hanya dipakai pada industri rumah tangga, namun banyak juga digunakan sebagai material pesawat terbang, kapal, mobil, dan bidang kontruksi yang dalam penggunaanya sering kali memerlukan proses penyambungan[1]. Dalam perancangan suatu struktur pada komponen mesin, sering kali diperlukan sebuah proses penyambungan misalnya dengan pengelasan.

Pada proses penyambungan aluminium silinder pejal memiliki masalah dimana pengelasan cair tidak dapat menyambung hingga ke bagian dalam dari silinder pejal tersebut. Pengelasan gesek merupakan proses pengelasan yang dapat mengatasi permasalah penyambungan aluminium silinder pejal. Dilihat dari prosesnya 
ada beberapa jenis friction welding, di antaranya: friction stir welding, linear friction welding dan continuous drive friction welding [2].

Continuous drive friction welding (CDFW) adalah proses pengelasan solid state dimana satu bagian bergerak berputar dengan putaran tertentu serta diberikan tekanan ke bagian benda satunya yang menahan secara stasioner. Dalam jenis ini, panas dihasilkan oleh konversi energi mekanik menjadi energi termal pada permukaan dua buah logam karena rotasi di bawah tekanan. Pengelasan gesekan melibatkan kerja termomekanis yang menghasilkan perbaikan butir dari zona las[3].

Keunggulan Continous drive friction welding adalah waktu pengelasan yang relatif cepat dan mampu digunakan pada logam dengan weldability rendah, seperti aluminium[4]. Keuntungan lainnya adalah dapat menghemat material, menyambung benda bulat maupun tidak bulat, dapat menyambung material yang serupa maupun menyambung material yang berbeda jenisnya. Tidak hanya aluminium, logam-logam lain seperti stainless steel atau bahkan aluminium dan stainless steel[5].

Mendapatkan hasil pengelasan yang baik perlu diperhatikan parameter yang terdapat dalam proses pengelasan. Terdapat beberapa parameter proses pengelasan gesek (continuous drive friction welding) yaitu, rotational speed, friction time, friction pressure, upset time, upset pressure, dan geometri dari benda kerja yang bergesekan[6].

Variasi pengaruh kecepatan putar, weld time, dan burn off length (BOL) terhadap temperatur permukaan diharapkan dapat meningkatkan hasil pengelasan. Penggunaan BOL yang tinggi dengan weld time yang rendah menimbulkan stress yang tinggi sehingga material yang dihasilkan kurang kuat, sedangkan BOL yang rendah dengan weld time yang rendah menghasilkan difusi logam yang rendah sehingga material yang dihasilkan kurang kuat. Kekerasan yang tinggi dicapai pada material yang mengalami gesekan dan suhu tinggi karena adanya rekristalisasi pada material[7]. Dengan variasi BOL yang tinggi semakin besar heat input sehingga tegangan sisa yang dihasilkan semakin tinggi selain itu bentuk flash dapat disimulasikan dengan baik mendekati hasil eksperimental[8]. Dalam eksperimen mengenai pengaruh sudut chamfer dan gaya tekan akhir terhadap kekuatan tarik dan porositas sambungan las gesek pada paduan $\mathrm{Al}-\mathrm{Mg}-\mathrm{Si}$. Bahwa kekuatan tarik pada pengelasan gesek aluminium paduan Al-Mg-Si akan meningkat seiring dengan semakin kecilnya sudut chamfer dan semakin besarnya gaya tekan akhir[9].

Hingga saat ini, telah banyak penelitian mengenai Continuous Drive Friction Welding.dengan memvariasikan sudut chamfer, upset pressure dan burn off length yang dilakukan secara eksperimental maupun secara numerik. Namun demikian, penelitian yang menganalisa dengan menggunakan simulasi untuk melihat luasan area terdeformasi plastis penuh ( $\mathrm{Zpl}$ ) yang merupakan bagian dari heat affected zone dan distribusi suhu belum ditemui pada literature. Oleh karena itu, tujuan dari penelitian ini adalah untuk mengetahui luas area $(\mathrm{Zpl})$ dan distribusi suhu pada permukaan daerah pengelasan sehingga mendapatkan analisa baru pada proses pengelasan gesek.

\section{METODE DAN BAHAN}

Metode penelitian yang digunakan dalam penelitian ini adalah simulasi komputer dengan software ANSYS 18.1 Model geometri yang digunakan dalam penelitian ini solid pejal dengan panjang spesimen $260 \mathrm{~mm}$ seperti pada Gambar 1. Software ini diatur dengan menggunakan analisis transient thermal dengan analisis static structural.

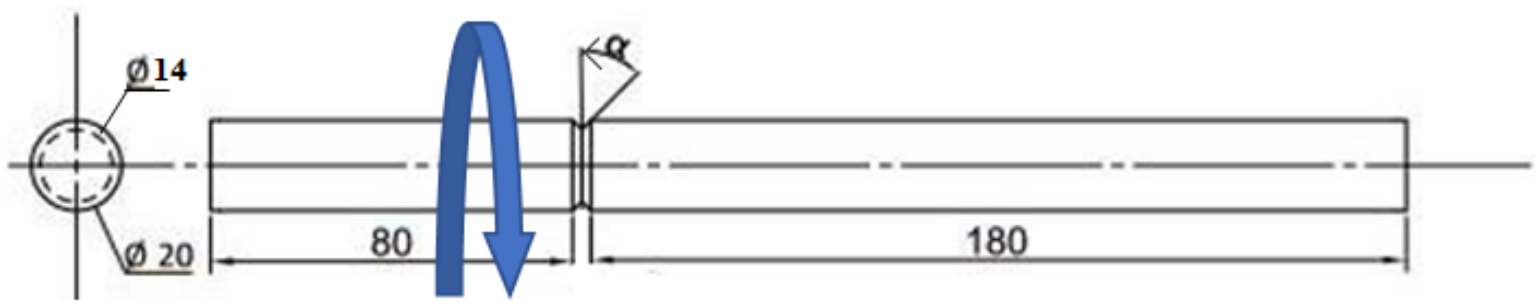

Gambar 1: Dimensi Aluminum 6061 pengelasan gesek (mm) dengan variasi sudut $\alpha: 15^{\circ}, 30^{\circ}, 45^{\circ}$

Penelitian ini menggunakan material aluminium tipe Al 6061-T4 menggunakan bilinier isotropic hardening seperti yang terlihat pada Tabel 1. 
Tabel 1: Properti material

\begin{tabular}{c|c|c|c|c|c}
\hline $\begin{array}{c}\text { Suhu } \\
\left({ }^{\circ} \mathbf{C}\right)\end{array}$ & $\begin{array}{c}\text { densitas } \\
\left(\mathbf{k g} / \mathbf{m}^{3}\right)\end{array}$ & $\begin{array}{c}\text { Modulus Young } \\
(\mathbf{G P a})\end{array}$ & $\begin{array}{c}\text { Yield Strength } \\
(\mathbf{M P a})\end{array}$ & $\begin{array}{c}\text { Konduktivias Termal } \\
\left(\mathbf{W} / \mathbf{m}^{\circ} \mathbf{C}\right)\end{array}$ & $\begin{array}{c}\text { Spesific Heat } \\
\left(\mathbf{J} / \mathbf{k g}^{\circ} \mathbf{C}\right)\end{array}$ \\
\hline 37.8 & 2690 & 68.5 & 274 & 945 & 945 \\
\hline 93.3 & 2690 & 66.2 & 265 & 978 & 978 \\
\hline 149 & 2670 & 63.1 & 248 & 1000 & 1000 \\
\hline 204 & 2660 & 59.2 & 219 & 1030 & 1030 \\
\hline 260 & 2660 & 54 & 160 & 1052 & 1080 \\
\hline 316 & 2630 & 47.5 & 66.2 & 1080 & 1100 \\
\hline 371 & 2630 & 40.3 & 34.5 & 1100 & 1130 \\
\hline 427 & 2600 & 31.7 & 17.9 & 1130 & \\
\hline
\end{tabular}

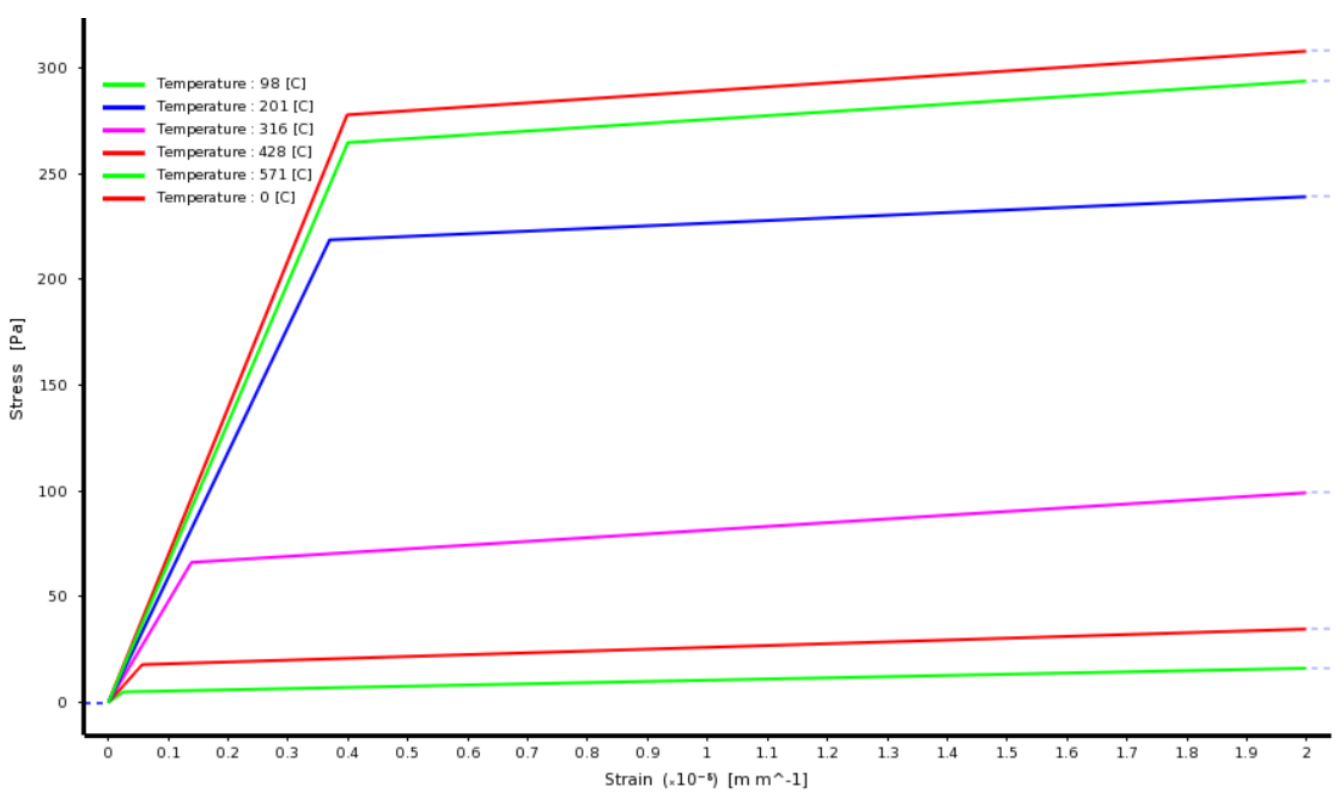

Gambar 2: Grafik tegangan-regangan material aluminium AA 6061 T4 [15]

Dapat dilihat pada Gambar 2 Pemodelan material pada Aluminium dengan Bilinear Isotropic Hardening, dimana sebuah material mengalami deformasi elastis ketika diberikan pembebanan menjadi deformasi plastis. Gambar 3 menunjukkan skematik benda kerja yang terdiri dari 2 spesimen. Spesimen pertama diputar dengan rotational speed sebesar $1600 \mathrm{rpm}$ dan spesimen kedua ditekan dengan friction pressure sebesar $21 \mathrm{kN}$ selama 2 detik. Sudut chamfer, burn-off length dan upset pressure divariasikan Sesuai dengan variabel bebas. Dan dengan Variabel terkontrol adalah variabel yang nilainya tetap selama proses penelitian berlangsung koefisien gesek 0.3, kecepatan putar sebesar $1600 \mathrm{rpm}$ dan Friction Pressure sebesar $7 \mathrm{kN}$ selama 2 detik. Dan heat flux diterapkan pada kedua benda kerja yang bergesekan. Dengan rumus [6]:

$$
\dot{\mathrm{Q}}=\frac{2}{3} \pi \cdot \mu \cdot \omega \cdot P \cdot R^{3}
$$

Dengan $\dot{Q}$ adalah jumlah energi per satuan waktu yang terjadi permukaan las (Watt) $(1$ Watt $=0.2388$ kalori/s), $P$ adalah Friction pressure (N/m² $), \omega$ adalah Kecepatan sudut ( $\mathrm{rad} / \mathrm{s}) . R$ adalah Radius benda kerja/ permukaan yang bergesekan (m) dan $\mu$ merupakan Koefisien gesek. 

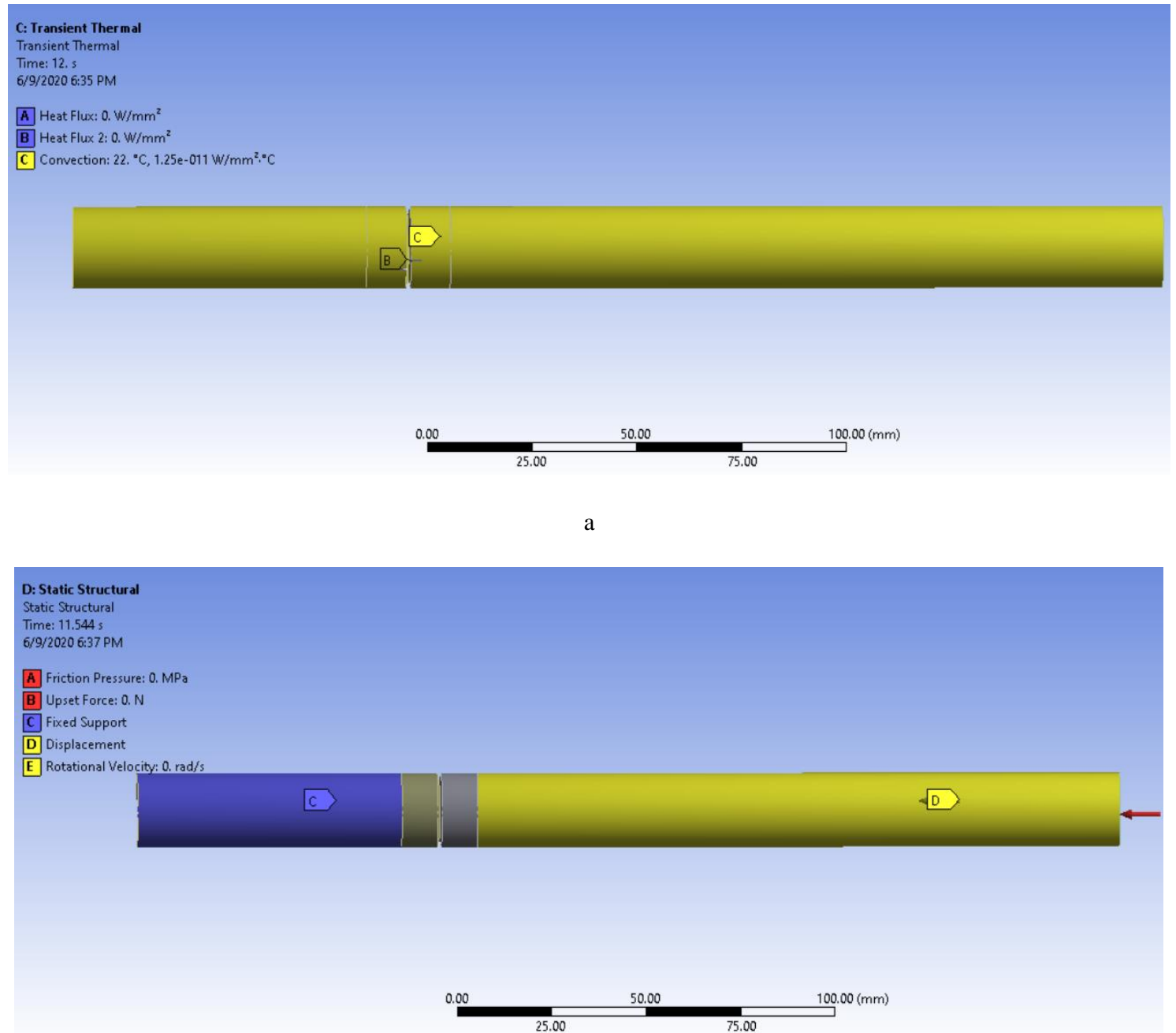

b

Gambar 3: Permodelan pembebanan pegelasan gesek pada Aluminium 6061 a). Permodelan Transient Thermal,

b). Permodelan Static Structural

Metode Taguchi digunakan untuk mengoptimalkan kinerja dan menentukan parameter yang terbaik dengan jumlah eksperimen yang dianalisis lebih sedikit daripada desain faktorial. Semakin banyak jumlah level yang diteliti maka hasil eksperimen Taguchi semakin teliti disebabkan jumlah data yang diperoleh banyak [10]. Faktor dan level yang digunakan dalam penelitian ini adalah Sudut chamfer, burn-off length dan upset pressure seperti pada Tabel 2.

Tabel 2: Faktor dan Level dari Faktor

\begin{tabular}{c|c|c|c|c|c}
\hline \multirow{2}{*}{ FAKTOR KONTROL } & \multirow{2}{*}{ UNIT } & \multirow{2}{*}{ NOTASI } & \multicolumn{4}{|c}{ LEVEL } \\
\cline { 4 - 6 } & & & 1 & 2 & 3 \\
\hline Sudut Chamfer & $\circ$ & $\mathrm{A}$ & 15 & 30 & 45 \\
\hline Burn off length & $\mathrm{mm}$ & $\mathrm{B}$ & 7 & 8 & 9 \\
\hline Upset pressure & $\mathrm{M} \mathrm{pa}$ & $\mathrm{C}$ & 120 & 220 & 240 \\
\hline
\end{tabular}

Penelitian ini menggunakan karakteristik distribusi suhu dan daerah HAZ . Pemilihan orthogonal array berdasarkan perhitungan degree of freedom (DOF), orthogonal array yang dipilih harus lebih tinggi dari perhitungan degree of freedom. Dengan demikian, orthogonal array yang digunakan yaitu $L_{9}\left(3^{3}\right)$ seperti pada Tabel 3. 
Tabel 3: Orthogonal array $\mathrm{L}_{9}\left(3^{3}\right)[14]$ :

\begin{tabular}{c|c|c|c|c}
\hline \multirow{2}{*}{$\begin{array}{c}\text { MODEL } \\
\text { SIMULASI }\end{array}$} & \multicolumn{3}{|c|}{ FAKTOR DAN INTERAKSI } & RESPON \\
\cline { 2 - 5 } & A & B & C & \\
\hline 1 & 1 & 1 & 1 & \\
\hline 2 & 1 & 2 & 2 & \\
\hline 3 & 1 & 3 & 3 & \\
\hline 4 & 2 & 1 & 2 & \\
\hline 5 & 2 & 2 & 3 & \\
\hline 6 & 2 & 3 & 1 & \\
\hline 7 & 3 & 1 & 3 & \\
\hline 8 & 3 & 2 & 1 & \\
\hline 9 & 3 & 3 & 2 & \\
\hline
\end{tabular}

\section{HASIL DAN DISKUSI}

\subsection{Verifikasi Data Penelitian Yang Sebelumnya Mengenai Pengaruh Sudut Chamfer Terhadap Luas} Zone Fully Plasticized.

Verifikasi dilakukan dengan tujuan supaya data yang didapatkan bisa mendekati data yang ada atau sudah dilakukan eksperimen sebelumnya. Pada bagian ini akan dilakukan perbandingan data antara data eksperimen dengan data simulasi yang telah dilakukan.

Pada penelitian yang telah dilakukan sebelumnya[11] mengenai pengaruh sudut chamfer terhadap Luas Zone Fully Plasticized. Hasil dari penelitian tersebut didapatkan panjang flash arah vertikal untuk sudut chamfer $15^{\circ}$ memiliki panjang sebesar $25.774 \mathrm{~mm}$, tinggi flash diukur dari bagian luar diameter bahan sebesar $2.78 \mathrm{~mm}$. Sedangkan panjang flash untuk arah horizontal sebesar $7.46 \mathrm{~mm}$. Pada Gambar $4 \mathrm{~b}$ ) telah dijelaskan dimana panjang flash pada eksperimen nyata berada.

Pada Gambar 4a) memberikan informasi data yang telah didapat pada simulasi yang telah dilakukan menunjukkan panjang flash arah vertikal sebesar $25.8097 \mathrm{~mm}$, tinggi flash diukur dari bagian luar diameter bahan sebesar $2.8587 \mathrm{~mm}$. Sedangkan panjang flash untuk arah horizontal sebesar $13.1442 \mathrm{~mm}$. Hal ini tidak berbeda jauh dengan eksperimen. Dengan perbedaan yang tidak terlalu jauh yakni 4,5\% maka data yang didapatkan pada simulasi ini sudah mendekati eksperimen. Hal ini disebabkan suhu lingkungan pada eksperimen sedikit berubah sedangkan pada simulasi tidak.

d

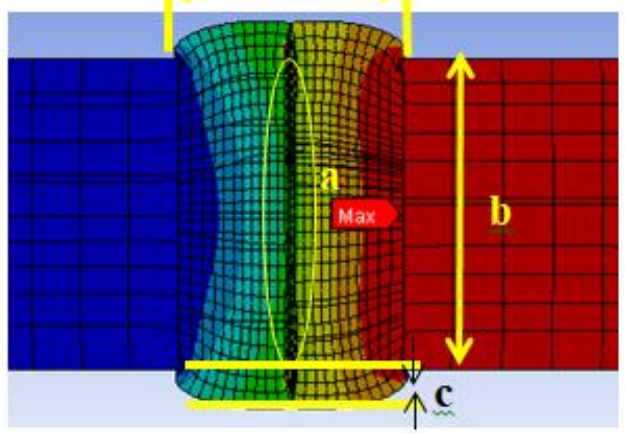

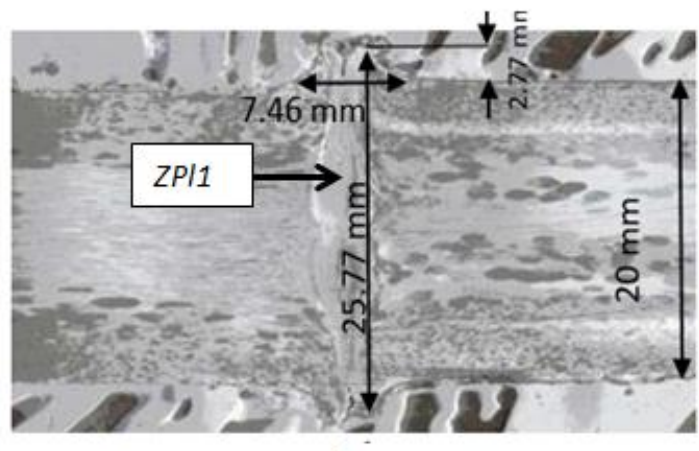

$\mathrm{b}$

Gambar 4: Hasil Flash a). Flash pada simulasi variasi sudut $15^{\circ}$, b) Flash pada eksperimen variasi sudut $15^{\circ}$

Pada penelitian yang telah dilakukan sebelumnya [11], hasil penelitian tersebut didapatkan luas area untuk sudut chamfer $15^{\circ}$ memiliki luas area sebesar $21.748 \mathrm{~mm}^{2}$. Luas wilayah tersebut terletak pada area yang memiliki suhu tertinggi. Pada proses pengambilan data secara eksperimen nyata dilakukan dengan mengukur wilayah tertentu. Ada beberapa ketentuan dalam memilih zona tersebut. Pada gambar 4 (b) telah dijelaskan dimana zone fully plasticized pada eksperimen nyata berada.

Pada gambar 4(a) memberikan informasi data telah didapatkan pada simulasi dengan keterangan (b) yang telah dilakukan menunjukkan luas wilayah zone fully plasticized 1 memiliki luas wilayah sebesar $21.814 \mathrm{~mm}^{2}$ dengan menggunakan imageJ. Hal ini tidak berbeda jauh dengan eksperimen yang menunjukkan luas sebesar $21.748 \mathrm{~mm}^{2}$. Dengan perbedaan yang tidak jauh yakni $0.33 \%$. Maka data yang didapatkan pada simulasi ini sudah mendekati eksperimen. 


\subsection{Verifikasi Data Penelitian Yang Sebelumnya Mengenai Pengaruh Sudut Chamfer Terhadap Luas} Zone Fully Plasticized.

Gambar 5 memberikan informasi data suhu maksimum pada simulasi pengelasan gesek sebesar $174.61{ }^{\circ} \mathrm{C}$ dan suhu tertinggi terdapat pada permukaan benda yang bergesekan.

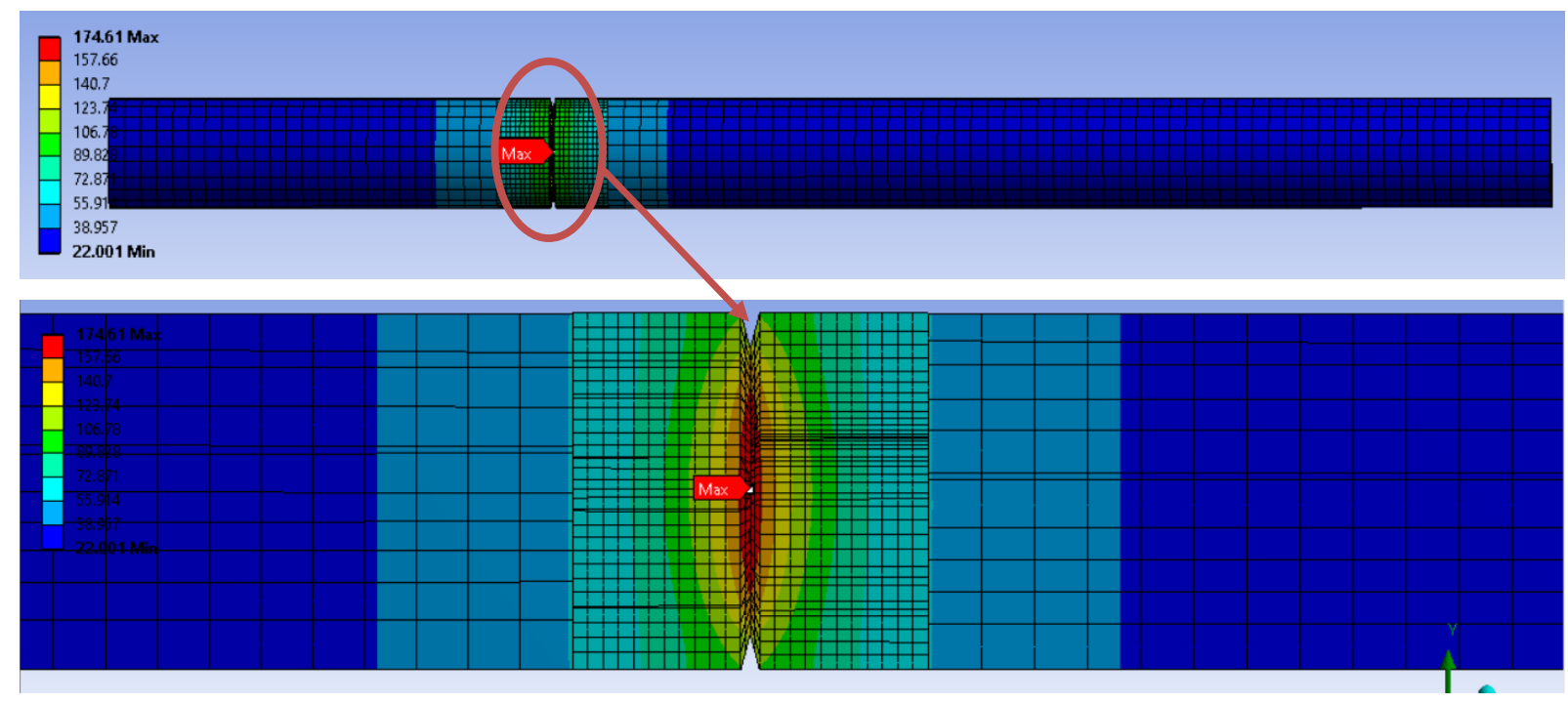

Gambar 5: Suhu maksimum pada pengelasan dengan simulasi $15^{\circ}$, dan letak suhu maksimum simulasi pada permukaan pengelasan yang bergesekan variasi sudut $15^{\circ}$

Tabel 4: Perbandingan Suhu Simulasi dengan True Experimental

\begin{tabular}{c|c|c}
\hline $\begin{array}{c}\text { SUHU MAKSIMUM METODE } \\
\text { SIMULASI (ํㅜ) }\end{array}$ & $\begin{array}{c}\text { SUHU MAKSIMUM METODE TRUE } \\
\text { EXPERIMENTAL (으) }\end{array}$ & $\begin{array}{c}\text { PERSENTASE ERROR } \\
(\%)\end{array}$ \\
\hline $174.61{ }^{\circ} \mathrm{C}$ & $167^{\circ} \mathrm{C}$ & $4.55 \%$ \\
\hline
\end{tabular}

Dengan membandingkan data pada table 4 yang didapat dengan eksperimen maka terdapat selisih suhu yang dimiliki, suhu maksimum pada simulasi lebih besar daripada suhu pada eksperimen. Suhu maksimum pada proses simulasi $15^{\circ}$ memiliki suhu $174.61^{\circ} \mathrm{C}$, sedangkan data eksperimen diambil suhu maksimum pada variasi sudut chamfer $15^{\circ}$ sebesar $167^{\circ} \mathrm{C}$. Dari kedua data diambil selisih suhunya, persentase selisih dari kedua data tersebut adalah $4.55 \%$. Dari kedua data tersebut terdapat perbedaan yang disebut presentase error dari nilai temperatur. Hal ini disebabkan beberapa hal antara lain

1. Permodelan material simulasi memakai bilinear isotopric hardening yang bentuknya lurus pada daerah elastis dan plastis sehingga asumsi permodelan material akan memberikan perbedaan nilai.

\subsection{Data Efek Upset Force Dan Sudut Chamfer Terhadap Distribusi Suhu Pada Permukaan Benda Kerja}

Berikut ini akan membahas mengenai efek sudut chamfer, upset pressure dan burn off length terhadap distribusi suhu. Dibawah ini merupakan hasil distribusi suhu dari simulasi CDFW dengan berbagai model. Geometri pada model kali ini adalah menggunakan sudut Chamfer sebesar $15^{\circ}$. Dari gambar tersebut didapatkan informasi bahwa letak suhu maksimal ditandai dengan warna merah. Untuk warna biru tua menandakan suhu minimum.

Dimana didapatkan nilai suhu maksimal terbesar pada sampel 3 seperti pada gambar 6. Terlihat bahwa suhu maksimal yang terjadi pada permukaan yang bergesekan mencapai $192.48{ }^{\circ} \mathrm{C}$ ditandai dengan warna merah. Daerah HAZ merupakan daerah sekiar interface yang mengalami suhu minimal rekristalisasi yaitu 0,4 daru suhu cair Aluminium. 


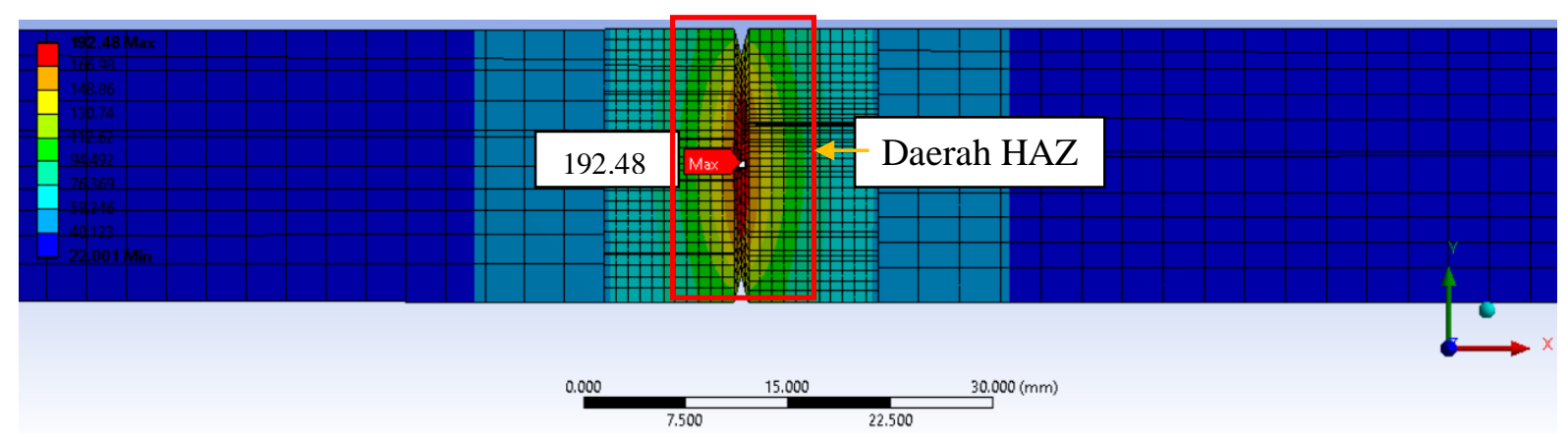

Gambar 6 Sampel 3 : Distribusi Suhu $\left({ }^{\circ} \mathrm{C}\right)$ Sudut Chamfer $15^{\circ}$, upset pressure $240 \mathrm{MPa}$ dan burn off length $9 \mathrm{~mm}$ dari tampilan potongan memanjang

Pada gambar 7 didapatkan nilai suhu maksimal terendah pada sampel 3. Terlihat bahwa suhu maksimal yang terjadi pada permukaan yang bergesekan mencapai $169.01{ }^{\circ} \mathrm{C}$ ditandai dengan warna merah. Daerah HAZ merupakan daerah sekiar interface yang mengalami suhu minimal reskritalisasi yaitu 0,4 dari suhu cair Aluminium.

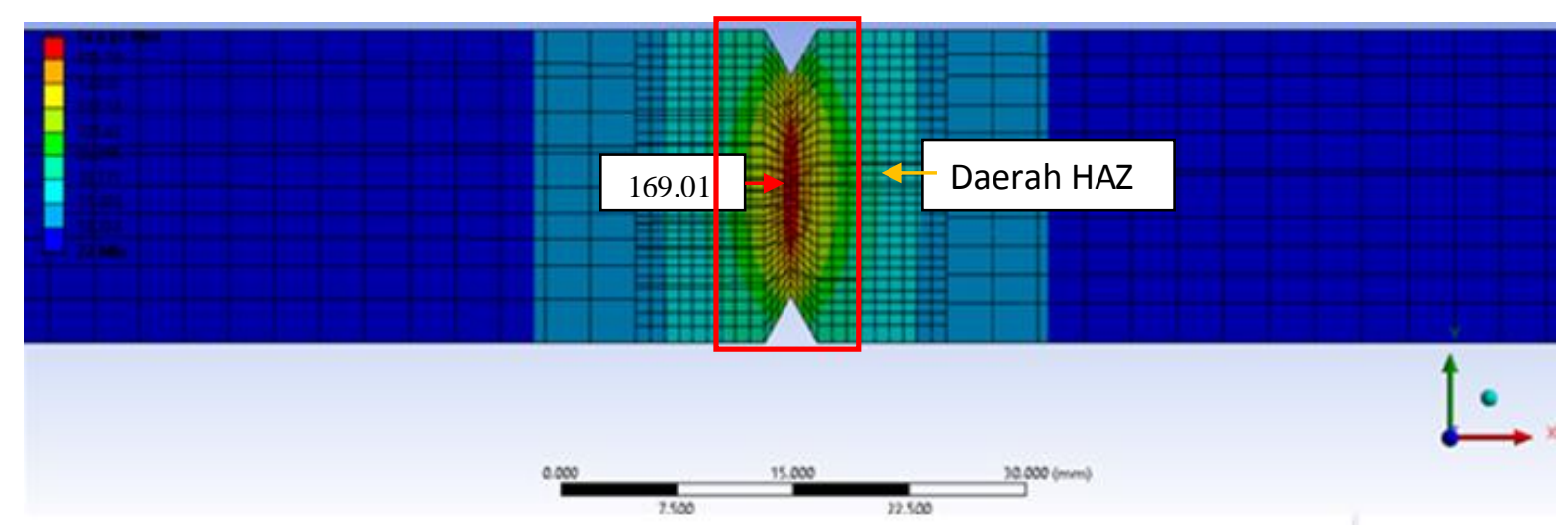

Gambar 7 Sampel 6: Distribusi Suhu $\left({ }^{\circ} \mathrm{C}\right)$ Sudut Chamfer $30^{\circ}$, upset pressure $120 \mathrm{MPa}$ dan burn off length $9 \mathrm{~mm}$ dari tampilan potongan memanjang

Dari semua simulasi yang dilakukan didapatkan tabel 5 yaitu distribusi suhu semua sampel. Dengan geometri sudut chamfer 15,30, dan 45 derajat. Upset pressure $120 \mathrm{MPa}, 220 \mathrm{MPa}$, dan $240 \mathrm{Mpa}$ serta burn off length 7, 8, $9 \mathrm{~mm}$.

Tabel 5 Data suhu maksimum Benda kerja.

\begin{tabular}{c|c|c|c|c}
\hline SAMPEL & $\begin{array}{c}\text { SUDUT } \\
\text { CHAMFER }\end{array}$ & $\begin{array}{c}\text { UPSET PRESSURE } \\
(\mathbf{M P a})\end{array}$ & $\begin{array}{c}\text { BURN OFF LENGTH } \\
(\mathbf{m m})\end{array}$ & $\begin{array}{c}\text { SUHU MAKSIMUM PADA } \\
\text { PERMUKAAN SAMBUNGAN ( }\end{array}$ \\
\hline 1 & 15 & 120 & 7 & 185.11 \\
\hline 2 & 15 & 220 & 8 & 189.23 \\
\hline 3 & 15 & 240 & 9 & 192.48 \\
\hline 4 & 30 & 220 & 8 & 172.51 \\
\hline 5 & 30 & 240 & 9 & 169.01 \\
\hline 6 & 30 & 120 & 7 & 175.56 \\
\hline 7 & 45 & 240 & 8 & 180.88 \\
\hline 8 & 45 & 120 & 9 & \\
\hline 9 & 45 & 220 & 8.22 & \\
\hline
\end{tabular}


Dari table 5 data suhu maksimum Benda kerja Sudut chamfer sangat berpengaruh terhadap kekuatan tarik sambungan las gesek, pengaruh dari sudut chamfer dan pemberian gaya tekan akhir atau upset pressure diatas $120 \mathrm{MPa}$ dapat meningkatkan kekuatan tarik dari sambungan las gesek[12]. Semakin besarnya sudut chamfer maka permukaan dari kedua benda yang saling bergesekan akan semakin luas. Dengan luas permukaan yang besar akan menghasilkan suhu yang tinggi pula. Ditambah dengan upset force yang tinggi, akan meningkatkan suhu dari benda kerja pula.

\subsection{Analisa Efek Upset Force Dan Sudut Chamfer Terhadap Distribusi Suhu Pada Benda Kerja}

Gambar 8 memberikan informasi mengenai suhu maksimum pada semua variasi. Suhu maksimum tertinggi di dapat dari model 3, dengan variasi sudut chamfer $15^{\circ}$ upset pressure $240 \mathrm{MPa}$ dan burn-off length $9 \mathrm{~mm}$ sebesar $192.48{ }^{\circ} \mathrm{C}$, disusul dengan burn-off length $8 \mathrm{~mm}$ dengan besar $189.23{ }^{\circ} \mathrm{C}$ dan burn-off length $7 \mathrm{~mm}$ dengan besar $185.11^{\circ} \mathrm{C}$. Suhu Maksimum terendah diperoleh dari model 6 dengan variasi sudut chamfer $30^{\circ}$ upset pressure $120 \mathrm{MPa}$ dan burn-off length $9 \mathrm{~mm}$ sebesar $169.01{ }^{\circ} \mathrm{C}$. Dari data pada gambar 8 , dapat disimpulkan bahwa semakin besar upset pressure serta burn off length, maka suhu maksimum akan semakin tinggi karena luas permukaan yang bergesekan akan semakin kecil. Sehingga pada saat diberikan upset force, tekananannya akan semakin besar serta meningkatkan heat input saat pengelasan. Besar peningkatan tekanan didapat pada rumus berikut :

$$
P=4 f \pi d^{2}
$$

Dengan $P$ adalah Friction Pressure $(\mathrm{MPa}), f$ adalah Upset Force $(\mathrm{kN})$ dan $\mathrm{d}$ adalah Diameter permukaan gesek (mm).

Burn-off length juga berpengaruh dalam peningkatan suhu maksimum. Semakin besar Burn-off length maka suhu semakin tinggi karena bagian benda kerja yang bergesekan dan terdeformasi akan semakin banyak, sehingga heat input akan meningkat.

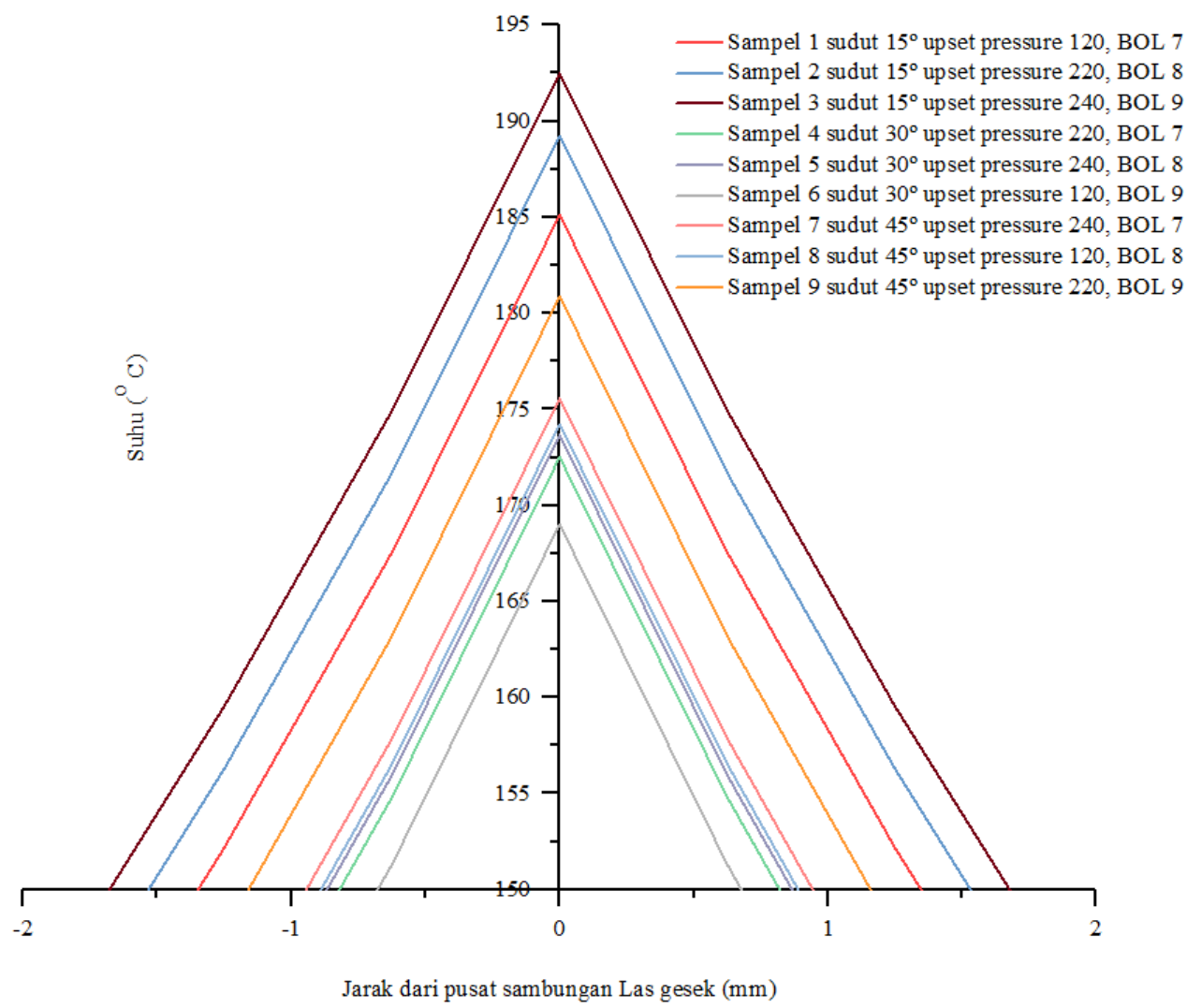

Gambar 8 Distribusi suhu pada saat pengelasan pengaruh variasi sudut chamfer, upset pressure, dan burn-off length terhadap seluruh model variasi.

Gambar 8 merupakan grafik mengenai pengaruh variasi sudut chamfer, upset pressure, dan burn-off length terhadap distribusi suhu pada saat pengelasan. Pada grafik dapat dilihat bahwa model 3 dengan variasi 
sudut chamfer $15^{\circ}$ upset pressure $240 \mathrm{MPa}$ dan burn-off length $9 \mathrm{~mm}$ memiliki distribusi suhu paling luas dan suhu maksimum tertinggi. Model 6 dengan variasi variasi sudut chamfer $30^{\circ}$ upset pressure $120 \mathrm{MPa}$ dan burn-off length $9 \mathrm{~mm}$ memiliki distribusi suhu paling sempit dan suhu maksimum terendah.

Dapat dilihat bahwa semakin kecil sudut chamfer dengan peningkatan upset pressure dan burn-off length yang semakin besar membuat distribusi suhu pada saat pengelasan semakin luas dan suhu maksimumnya semakin tinggi. Hal ini disebabkan karena semakin besar burn-off length maka bagian dari benda kerja yang bergesekan akan semakin luas, yang membuat heat input yang dihasilkan akan semakin besar. Akibatnya, distribusi suhu akan lebih luas dan lebih merata karena deformasi yang terjadi akibat pengelasan lebih luas. Selain itu, daerah HAZ yang semakin luas akan meningkatkan kekuatan tarik dari sambungan pada las gesek[13].

Dari deskripsi tersebut, maka model 3 dengan variasi sudut chamfer $15^{\circ}$, upset pressure $240 \mathrm{MPa}$ dan burn-off length $9 \mathrm{~mm}$ merupakan model yang paling optimal dalam meningkatkan kekuatan tarik sambungan. Dalam pengelasan dikenal istilah daerah yang terpengaruh panas akibat pengelasan, atau heat affected zone (HAZ). Zpd atau partly deformed zone yakni daerah HAZ yang mengalami deformasi sebagian yang diakibatkan oleh proses pengelasan ditandai dengan telah memasuki temperatur deformasi plastis akibat panas[15]. Untuk material Al 6061-T4 sebesar 198 [14].

\subsection{Data Efek Double Chamfer, Upset Pressure dan Burn Off Length Terhadap Luas Zone Fully Plasticized.}

Berikut ini akan membahas mengenai efek double chamfer, upset pressure dan burn-off length terhadap Luas Zone Fully Plasticized. Dengan menggunakan berbagai macam model yang sudah dijelaskan pada metode penelitian pada bab sebelumnya. Dibawah ini merupakan hasil dari Luas Zone Fully Plasticized dari simulasi CDFW dengan berbagai model. Geometri pada model kali ini adalah menggunakan sudut Chamfer sebesar $15^{\circ}$ yang diberikan pada model 1 upset Pressure $120 \mathrm{MPa}$ dan burn-off length $7 \mathrm{~mm}$, model 2 upset Pressure $220 \mathrm{MPa}$ dan burn-off length $8 \mathrm{~mm}$ dan model 3 upset Pressure $240 \mathrm{MPa}$ dan burn-off length $9 \mathrm{~mm}$.

Pengambilan data luasan Zpl yang dipotong memanjang dengan menggunakan imageJ seperti pada gambar 9. terlihat symbol a menunjukan zone fully plasticized (Zpl), symbol b menunjukkan panjang flash, symbol c merupakan tinggi flash diukur dari bagian luar diameter dan symbol d merupakan panjang flash untuk arah horizontal.

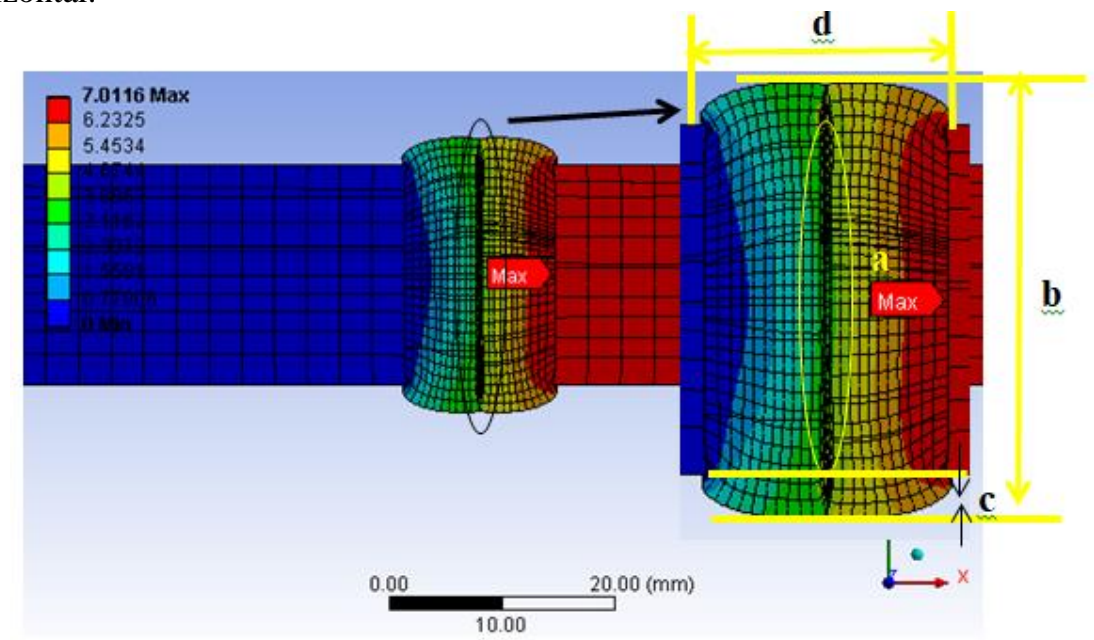

Gambar 9: Pengambilan data luasan Zpl yang dipotong memanjang dengan menggunakan imageJ

Pada Gambar 10a memberikan informasi data yang telah didapat pada simulasi menunjukkan luas wilayah zone fully plasticized 1 model 1 memiliki ZPl1 sebesar $13.042 \mathrm{~mm}^{2}$, panjang flash arah vertikal simbol sebesar $25.156 \mathrm{~mm}$, tinggi flash diukur dari bagian luar diameter bahan simbol sebesar $2.578 \mathrm{~mm}$. Sedangkan panjang flash untuk arah horizontal simbol sebesar $14.36 \mathrm{~mm}$.

Gambar 10b model 2 memiliki ZP11 sebesar $11.815 \mathrm{~mm}^{2}$, panjang flash arah vertikal simbol sebesar $25.889 \mathrm{~mm}$, tinggi flash diukur dari bagian luar diameter bahan simbol sebesar $2.944 \mathrm{~mm}$. Sedangkan panjang flash untuk arah horizontal simbol sebesar $13.838 \mathrm{~mm}$.

Gambar 10c model 3 memiliki ZP11 sebesar $10.256 \mathrm{~mm}^{2}$, panjang flash arah vertikal simbol sebesar $26.494 \mathrm{~mm}$, tinggi flash diukur dari bagian luar diameter bahan simbol sebesar $3.247 \mathrm{~mm}$. Sedangkan panjang flash untuk arah horizontal simbol sebesar $13.1087 \mathrm{~mm}$. 


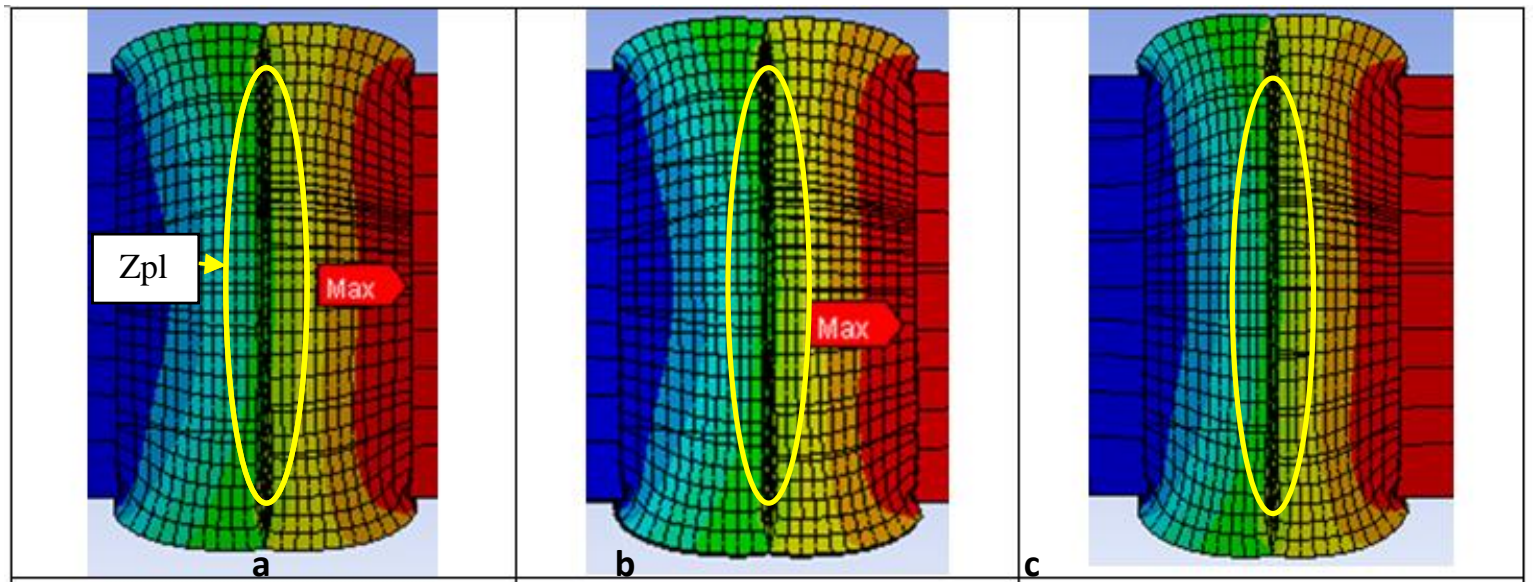

Gambar 10: Luas Zone Fully Plasticize pada chamfer $15^{\circ}$. a). Zpl model 1, b). Zpl model 2 dan c). Zpl model 3

Pada Gambar 11 Geometri pada model kali ini adalah menggunakan sudut chamfer sebesar $30^{\circ}$ yang diberikan pada model 4 upset Pressure $220 \mathrm{MPa}$ dan burn-off length $7 \mathrm{~mm}$, model 5 upset pressure $240 \mathrm{MPa}$ dan burn-off length $8 \mathrm{~mm}$ dan model 6 upset pressure $120 \mathrm{MPa}$ dan burn-off length $9 \mathrm{~mm}$.

Gambar 11a model 4 memberikan informasi data yang telah didapat pada simulasi menunjukkan luas wilayah zone fully plasticized 1 sebesar $34.69 \mathrm{~mm}^{2}$, panjang flash arah vertikal simbol sebesar $24.5 \mathrm{~mm}$, tinggi flash diukur dari bagian luar diameter bahan simbol sebesar $2.25 \mathrm{~mm}$. Sedangkan panjang flash untuk arah horizontal simbol sebesar $13.5 \mathrm{~mm}$.

Gambar 11b model 5 memiliki ZP11 sebesar $31.36 \mathrm{~mm}^{2}$, panjang flash arah vertikal symbol sebesar $26.056 \mathrm{~mm}$, tinggi flash diukur dari bagian luar diameter bahan symbol sebesar $3.028 \mathrm{~mm}$. Sedangkan panjang flash untuk arah horizontal simbol sebesar $13.365 \mathrm{~mm}$.

Gambar 11c model 6 memiliki ZP11 sebesar $30.619 \mathrm{~mm}^{2}$, panjang flash arah vertikal sebesar 26.666 $\mathrm{mm}$, tinggi flash diukur dari bagian luar diameter sebesar $3.333 \mathrm{~mm}$. Sedangkan panjang flash untuk arah horizontal simbol sebesar $12.669 \mathrm{~mm}$.

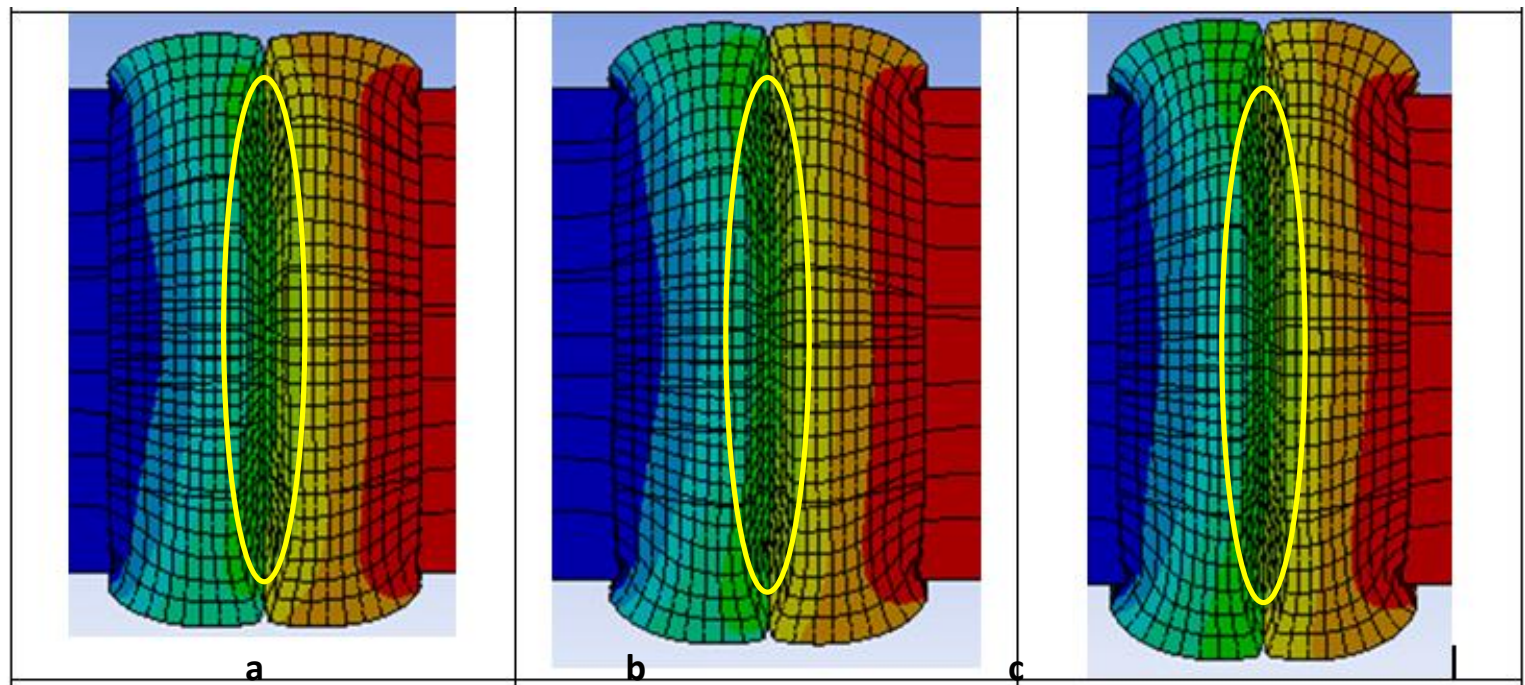

Gambar 11: Luas Zone Fully Plasticize pada chamfer $30^{\circ}$.a). Zpl model 4, b). Zpl model 5 dan c). Zpl model 6

Pada Gambar 12 Geometri pada model kali ini adalah menggunakan sudut chamfer sebesar $45^{\circ}$ yang diberikan pada model 7 upset Pressure $240 \mathrm{MPa}$ dan burn-off length $7 \mathrm{~mm}$, model 8 upset Pressure $120 \mathrm{MPa}$ dan burn-off length $8 \mathrm{~mm}$ dan model 6 upset Pressure $220 \mathrm{MPa}$ dan burn-off length $9 \mathrm{~mm}$.

Gambar 12a model 7 memberikan informasi data yang telah didapat pada simulasi menunjukkan luas wilayah zone fully plasticized sebesar $56.55 \mathrm{~mm}^{2}$, panjang flash arah vertikal simbol sebesar $24.190 \mathrm{~mm}$, tinggi flash diukur dari bagian luar diameter bahan simbol sebesar $2.095 \mathrm{~mm}$. Sedangkan panjang flash untuk arah horizontal simbol sebesar $13.428 \mathrm{~mm}$.

Gambar 12b model 8 memiliki ZP11 sebesar $49.33 \mathrm{~mm}^{2}$, panjang flash arah vertikal simbol sebesar $25.729 \mathrm{~mm}$, tinggi flash diukur dari bagian luar diameter bahan simbol sebesar $2.864 \mathrm{~mm}$. Sedangkan panjang flash untuk arah horizontal simbol sebesar $13 \mathrm{~mm}$. 
Gambar 12c model 9 memiliki ZPI1 sebesar $46.221 \mathrm{~mm}^{2}$, panjang flash arah vertikal sebesar $26.909 \mathrm{~mm}$, tinggi flash diukur dari bagian luar diameter bahan sebesar $3.454 \mathrm{~mm}$. Sedangkan panjang flash untuk arah horizontal sebesar $12.639 \mathrm{~mm}$

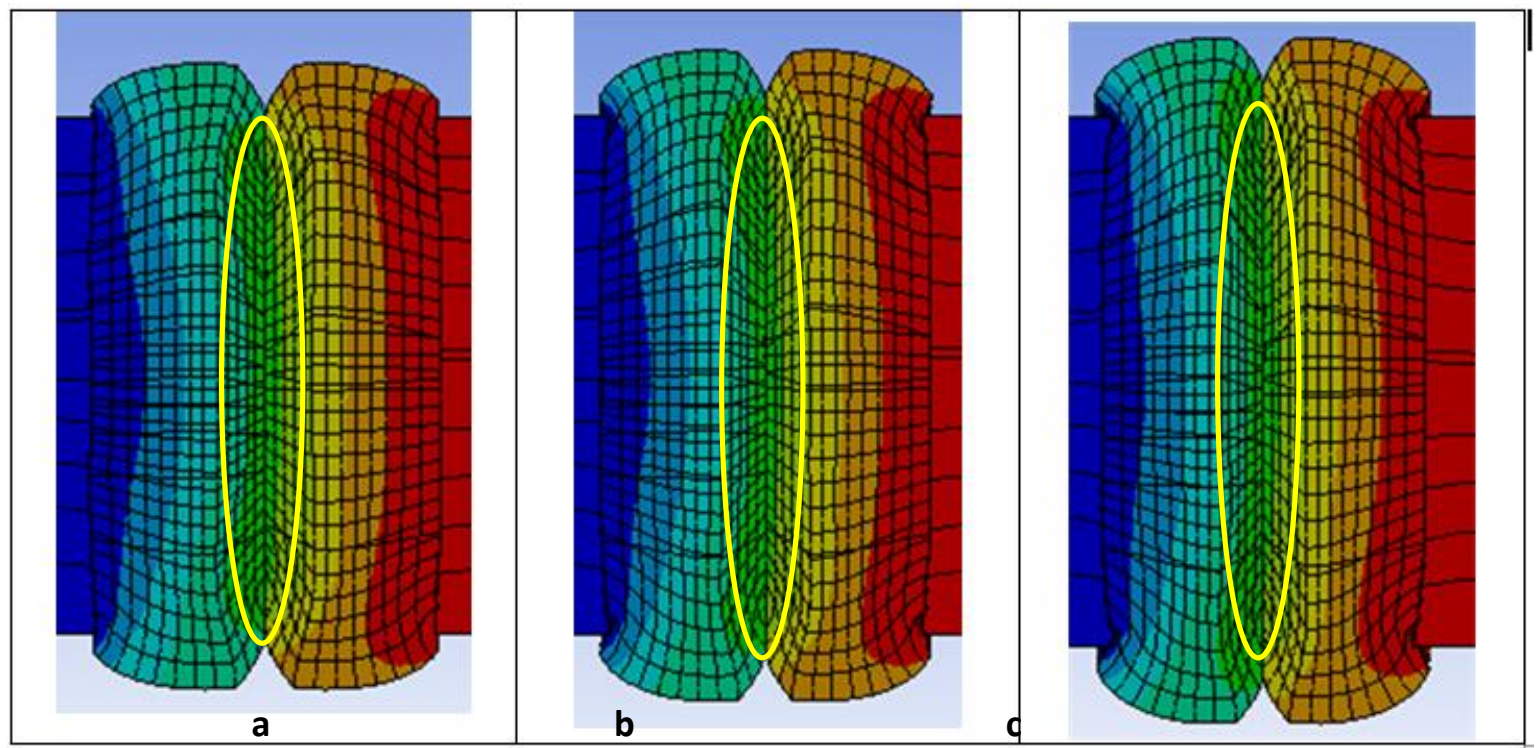

Gambar 12: Luas Zone Fully Plasticize pada chamfer $45^{\circ}$. a). Zpl model 7, b). Zpl model 8 dan c). Zpl model 9

Gambar 13 merupakan grafik yang menunjukkan luas area Zone Fully Plasticize (Zpl) seluruh model variasi. Menggunakan Image $\mathbf{J}$ untuk mengukur luas area yang dihasilkan dalam simulasi pada semua variasi. Dapat diketahui bahwa luas area paling kecil pada variasi sampel 3 dengan sudut chamfer $15^{\circ}$ dengan upset pressure $120 \mathrm{mpa}$ dengan burn-off length yang besar $9 \mathrm{~mm}$ mempunyai luas area zpl yang kecil yaitu $10.256 \mathrm{~mm}^{2}$, Berbeda dengan sudut $45^{\circ}$ dengan upset pressure $240 \mathrm{MPa}$ dengan burn-off length yang kecil $7 \mathrm{~mm}$ mempunyai luas area ZPl yang besar yaitu $56.55 \mathrm{~mm}^{2}$. Luas daerah zone fully plasticized yang sempit disebabkan oleh upset pressure yang diberikan sangat besar sebesar $240 \mathrm{MPa}$. Luas daerah zone fully plasticized menunjukkan seberapa besar material dapat menyatu satu dengan yang lainnya selama proses pengelasan dan seberapa besar kekuatan dari logam las. Terlihat pada gambar 10, 11 dan 12 terdapat gradient warna dari hasil simulasi pengelasan gesek. Gradien warna biru hingga merah menunjukkan deformasi yang dhasilkan semakin besar dikarenakan satu sisi logam dalam keadaan yang diam.

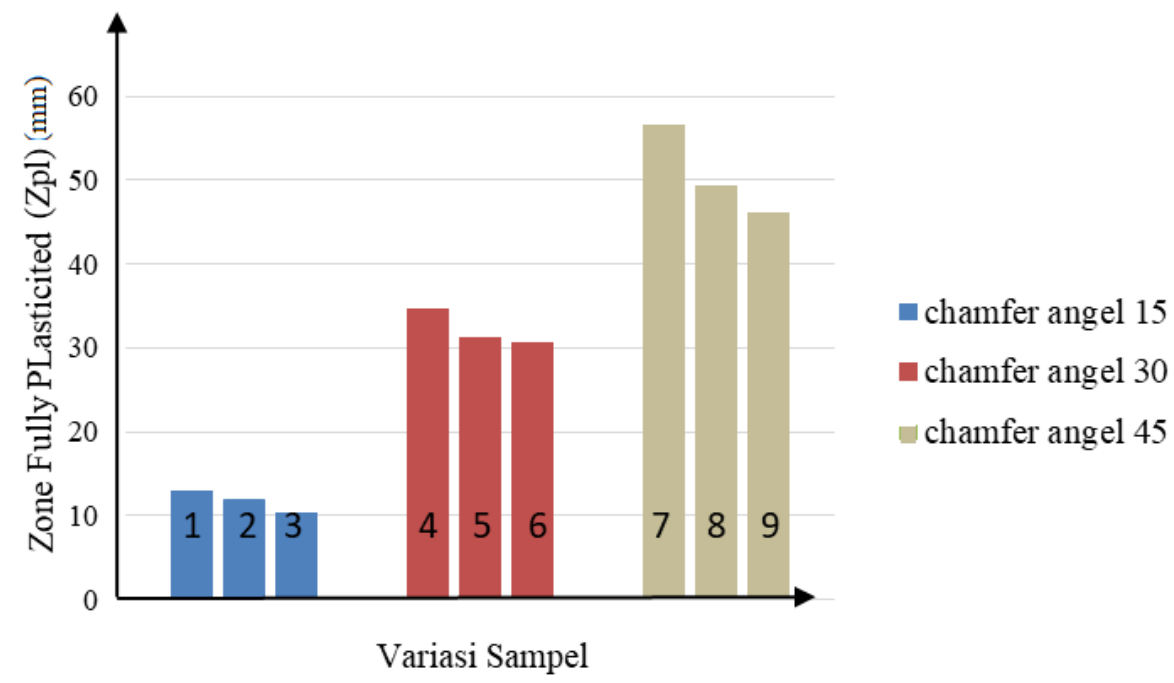

Gambar 13: Luas Zone Fully Plasticize pada seluruh model variasi

Secara umum bisa di tarik kesimpulan bahwa luas area ZPl cenderung meningkat dengan bertambahnya sudut chamfer yang diberikan,dan Panjang Flash vertikal cenderung bertambah besar bila tekanan akhir yang di berikan juga bertambah diikuti dengan burn off length yang meningkat. Sehingga menyebabkan kedua logam menyatu dan hasil perhitungan panjang Flash yang meningkat dengan bertambahnya burn-off length. 


\section{KESIMPULAN}

Berdasarkan hasil simulasi komputer pengelasan CDFW didapatkan bahwa double chamfer angle, burn off length (BOL) dan upset pressure berpengaruh terhadap distribusi suhu dan daerah Zpl pada sambungan Al6061. Luas area Zpl cenderung meningkat dengan bertambahnya double chamfer angle yang diberikan dan panjang flash vertikal cenderung bertambah besar bila tekanan akhir yang diberikan juga bertambah serta diikuti dengan burn off length yang meningkat, sehingga menyebabkan kedua logam menyatu. Semakin kecil double chamfer angle dengan peningkatan upset pressure dan burn off length yang semakin besar dengan luas gesekan yang sama membuat distribusi suhu pada saat pengelasan semakin luas dan suhu maksimumnya semakin tinggi. Hal ini disebabkan karena semakin besar burn off length maka bagian dari benda kerja yang bergesekan akan semakin luas, yang membuat heat input yang dihasilkan akan semakin besar. Akibatnya, distribusi suhu akan lebih luas dan lebih merata karena deformasi yang terjadi akibat pengelasan lebih luas. Model nomer 3 dengan variasi double chamfer angle $15^{\circ}$, upset pressure 240 MPa dan burn off length $9 \mathrm{~mm}$ yang menghasilkan kekuatan tarik sambungan paling tinggi dibandingkan model lainnya.

\section{PERNYATAAN TERIMAKASIH}

Penulis mengucapkan terima kasih kepada Studio Perancangan dan Rekayasa Sistem (SPRS) Teknik Mesin FT-UB atas fasilitas berupa software license ANSYS Academic Ver. 18.1 dalam pelaksanaan penelitian sampai penulisan karya tulis ini.

\section{DAFTAR PUSTAKA}

[1] SUKMANA,IRZA AND ADE SUSTIONO. "Pengaruh Kecepatan Putar Indentor Las Gesek (Friction Stir Welding) Terhadap Kekuatan hasil Pengelasan Aluminium 1100-H18," Jounal Mechanical Vol.7 No.1, 2016.

[2] KUMAR, SACHIN., BHARDWAJ, DEEPAK., AND SANGWAN, JAGDEEP. "A Research Paper on Temperature Modelling of Friction Welding of Aluminium and Stainless Steel-304.” 2014.

[3] G.S. CHNADER, G.M. REDDY, A.V. RAO. "Influence of rotational speed on microstructure and mechanical properties of dissimilar metal AISI 304-AISI 4140 continuous drive friction welds, J. Iron steel Res." Int 19 (2012) 64-73.

[4] N. RAJESH JESUDOSS HYNES AND S. RAJA. "Experimental study on joining of AA6063 and AISI 1040 steel. AIP Conference Proceeding" 1953, 130020. (2018); doi: 10.1063/1.5033164)

[5] TYAGITA, DICKY ADI, YUDY SURYA IRAWAN, AND WAHYONO SUPRAPTO. "Kekuatan Puntir Dan Porositas Hasil Sambungan Las Gesek AlMg-Si Dengan Variasi Chamfer Dan Gaya Tekan Akhir.” Jurnal Rekayasa Mesin 5(1):69-74. 2014.

[6] SAHIN, M., AND MISIRLI, C. "Mechanical and Metallurgical Properties of Friction Welded Aluminium Joints." Department. of Mechanical Eng., Trakya University, pp. 277-300. 2012.

[7] SANDEEP, KUMAR, RAJESH, KUMAR AND YOGESH, KUMAR SINGLA. "To Study The Mechanical Behaviour Of Friction Welding Of Aluminium Alloy And Mild Steel." Internatonal Journal of Mechanical Engineering and Robotics Research. 2012.

[8] ANGGARA, YOULANDA LOUIS., IRAWAN, YUDY SURYA., DAN CHOIRON, MOCH. AGUS. "Simulasi Tegangan Sisa Pada Sambungan Las Gesek Al6061 Dengan Metode Elemen Hingga." Jurnal Teknik Mesin Fakultas Teknik Universitas Brawijaya 2019.

[9] IRAWAN, Y.S., WIROHARDJO, M., AND MA'ARIF, S. "Tensile Strength of Weld Joint Produced by Spinning Friction Welding of Round Aluminum A6061 with Various Chamfer Angles." Advanced Materials Research, Vol. 576, pp. 761-765. 2012.

[10] I. SOEJANTO, "Rekayasa Kualitas : Eksperimen dengan Teknik Taguchi," Surabaya Yayasan Hum., 2009.

[11] IRAWAN, YUDY SURYA., IMAWAN, BUSTANUL., SOENOKO, RUDY. AND PURNOMO, HERY. "Effect of surface Roughness and Chamfer Angle on Tensile Strength of Round Aluminum A6061 Produced by Continuous Drive Friction Welding." Journal of Engineering and Applied Sciences. 6 (11) : 1179. 2016. 
[12] MURALIMOHAN, CHEEPU., AND WOO, SEONG CHE. "Effect of Burn-off Length on the Properties of Friction Welded Dissimilar Steel Bars." Journal of Welding and Joining 2019; 37(1): 40-45. DOI: https://doi.org/10.5781/JWJ.2019.37.1.6. 2019.

[13] LIN, C. B. LIN, C. K. MU, W. W. WU AND C. H. HUNG. "The Effect Of Joint Design and Volume Fraction On Friction Welding Properties Of A360/Sic (P) Composites." Welding Research Supplement. Department Of Mechanical Engineering. Tamkang University. Taiwan. 1999.

[14] YUSUF, AHMAD YASIN. "Pengaruh diameter dan sudut chamfer terhadap distribusi temperatur metode pengelasan cdfw logam al-6061 dengan logam ss-304." Jurnal Rekayasa Mesin. VI (11): 5766. 2016.

[15] WIRYOSUMARTO, HARSONO DAN TOSHIE OKUMURA. "Teknologi Pengelasan Logam". Jakarta: PT. Pradnya Paramita. 2000 